\title{
The Visegrad Group countries: The United Arab Emirates Perspective
}

\author{
ADAM KRZYMOWSKI \\ $S$ sciendo
}

Politics in Central Europe (ISSN: 1801-3422)

Vol. 17, No. 1

DOI: 10.2478/pce-2021-0005

\begin{abstract}
This manuscript analyses the role and importance of cooperation between the Visegrad Group (V4) countries and the most globally active member of the Gulf Cooperation Council (GCC), which is the United Arab Emirates. In view of the V4+ concept implemented with partners from the Middle East, Israel or Egypt, the presented analysis is important and meets the lack of this element in the scientific debate. This study is based on empirical research and its findings are the result of not only observation but also 10 years of direct participation of the author in many activities related to the cooperation of the Visegrad Group countries and the UAE, including as ambassador, senior advisor to Dubai Expo 2020, especially responsible for strategies and dynamisation relations between Central and Eastern Europe (except Poland) and the United Arab Emirates. According to the author's opinion, presented in the conclusion, there is now a huge opportunity to present V4 projects, including as a part of the broader strategy of the Three Seas Initiative (3SI) during World Expo Dubai, which will take place from October 2021 to March 2022, and make this initiative a globally recognizable project. However, coordinating and accelerating joint actions is required.
\end{abstract}

Keywords: Visegrad Group, United Arab Emirates, V4, European Union, GCC

\section{Introduction}

2021 is the $30^{\text {th }}$ anniversary of the Visegrad Group and the year of the $50^{\text {th }}$ anniversary of the establishment of the United Arab Emirates (UAE). In 2010, the Gulf Cooperation Council (GCC), of which the United Arab Emirates is an active member, was recognised by the $\mathrm{V} 4$ as a priority region of cooperation. 
The Visegrad Group (V4) is a regional cooperation platform of four Central European countries, i.e. Poland, the Czech Republic, Slovakia and Hungary, which are connected by neighbourhood, history, tradition, culture and geopolitical situation as well as similar strategic goals of foreign and security policy. In order to support each other in their implementation, especially in the context of integration with Euro-Atlantic structures, on February 151991, in Visegrad, Hungary, the presidents of Poland and Czechoslovakia, Lech Wałęsa and Václav Havel respectively, and the Hungarian Prime Minister, József Antall, signed a joint declaration setting out the goals and conditions for enhanced mutual cooperation. In 1993, after the emergence of the two sovereign states of the Czech Republic and Slovakia (from Czechoslovakia), this Visegrad Triangle turned into the V4, i.e. the Visegrad Group. In 2004, all V4 countries became members of the European Union, gaining the opportunity to co-shape the EU, pursue their own national interests within it, as well as co-decide about its future and the role and importance of the European Union in the world. In the new geopolitical situation, the Visegrad Group countries, in addition to cooperation in the areas of education, science and culture, have adopted as strategic goals the development of transport infrastructure and strengthening energy security in the region. Within the framework of the Visegrad Group cooperation, there is a network of diverse entities involved, with presidents, prime ministers, ministers, parliamentarians, various governmental organizations, NGOs, education, science and culture institutions. In addition, since 2000 the V4 has had an International Visegrad Fund (IVF) based in Bratislava. An important form of cooperation at the highest level is the presidency of the Visegrad Group, which is rotated to one of its members for a period of one year, which implements the program adopted by all leaders. From July 12020, to June 302021 , Poland holds the presidency of the V4. The Visegrad Group should be seen not only from the perspective of cooperation between the four countries but also in the external dimension of both the EU and each country of this initiative. The effective implementation of the interests of the Visegrad Group means that the region has more to offer, and thus increases the possibilities of their influence in international relations, including with non-European partners such as the United Arab Emirates.

The article aims to present the results of research on the significance of the GCC for the Visegrad Group, especially the bilateral relations between the V4 countries and the most dynamic member of the Gulf Cooperation Council, which is the United Arab Emirates. Moreover, the presented article answers the research question regarding the dynamics of the development of relations and its sources between the UAE and the countries of the Visegrad Group, and what the challenges and prospects are for this cooperation. Moreover, it answers the research question of what the role and significance are of this cooperation for a broader geostrategy, including the Three Seas Initiative as well as the United 
States of America and Israel. The topic of this article has an exceptional research importance, as it is the first such study on the Visegrad Group countries from the perspective of the United Arab Emirates, which significantly intensified their relations with this geographical area after 2010. These empirical studies and their findings are the results of not only observation but also 10 years of the author's direct participation in many initiatives regarding cooperation between the V4 countries and the United Arab Emirates, including as an ambassador, senior advisor to Dubai Expo 2020, also responsible for the strategy and dynamisation of all Central and Eastern European countries (except Poland) in relations with the United Arab Emirates.

\section{V4+ and GCC}

The establishment of the Gulf Cooperation Council (GCC) in 1981 and the Visegrad Triangle (later Group) in 1991 had similar intentions, but in different circumstances. The creation of the GCC was a response to drastic changes followed by the later appearance of the Islamic Republic of Iran, as well as the strengthening of Saddam Hussein's power in Iraq. The impetus for the establishment of the V4 was the dissolution of the Warsaw Pact and the collapse of the Soviet Union, which created a certain security vacuum in the area of Central and Eastern Europe. In view of this situation, Czechoslovakia, Poland and Hungary decided to jointly support each other in new strategic processes to ensure security and economic development by establishing the Visegrad Group. This was to be achieved by the V4's adoption of the same two pillars of foreign and security policies, i.e. integration with NATO and the European Union. It is worth mentioning that during the establishment of Visegrad cooperation, the war in the Persian (Arab) Gulf was beginning. Therefore, during the founding summit of the Visegrad Triangle (Group), its members analysed the war in the Persian (Arab) Gulf (Grabiński 2020).

The weakening USSR contributed both to the establishment of the Visegrad Group and influenced the war in the Persian (Arabian) Gulf as well acting as an impulse for new initiatives of the Gulf Cooperation Council. It should be noted, however, that the V4 and the GCC operate in a completely different geopolitical environment. The countries of the Visegrad Group are members of NATO, the most powerful military alliance, and the European Union, the most developed trading bloc in the world. By contrast, the Gulf Cooperation Council operates in one of the most volatile international environments in the world, with conflicts in which terrorist organisations operate, with failing states such as Iraq, Syria and Yemen, as well as with major tensions with Iran. The Visegrad Group and the GCC have great potential for cooperation that is not currently being used. Due to certain limitations in the deepening cooperation between the EU and the Gulf Cooperation Council resulting from the lack of an agreement 
that has been awaiting negotiation for 20 years, the V4 countries should, first of all, strengthen relations at the bilateral level. The V4 countries have strong agricultural. By contrast, the Gulf Cooperation Council must import about $90 \%$ of its food. In addition, the Visegrad Group countries are oil and gas importers, while in the GCC countries have large quantities of these resources. In the view of contemporary challenges and the 2030 UN Agenda, all countries of both groups are implementing economic diversification programmes, putting more and more emphasis on the green economy and renewable energies. It is worth mentioning that the capital of the United Arab Emirates has become the headquarters of the International Renewable Energy Agency.

The V4 is involved in a number of issues both within the European Union and outside the EU (Cabada - Waisová 2018: 9). It should be emphasised that the Visegrad Group, having the same number of votes in the EU Council as France and Germany, together has great potential for shaping the EU's Common Foreign and Security Policy. Therefore, attention should be paid to the activity of the Visegrad Group in the V4+ format, under which relations with Benelux, the African Union, the Scandinavian-Baltic States, South Korea and Japan were initiated (MOFAT 2017). The Visegrad Group also started its activity in the Middle East, initiating dialogue with countries such as Egypt, Israel and Lebanon. In 2010, the Slovak Presidency of the V4 set cooperation with the GCC as one of its priorities (Slovak Presidency 2010). The next presidency, held by the Czech Republic, also identified the Gulf Cooperation Council as a strategic partner, especially in attracting tourists to the V4 countries (Czech Presidency 2011). Then Hungary, which held its presidency in 2013-2014, emphasised the need to conduct promotional activities for tourists from the Visegrad Group countries in the Gulf Cooperation Council region (Hungarian Presidency 2013). As a result, on May 62014 , during the Arabian Travel Market (ATM), a promotional event which was the largest tourism fair in the Persian (Arab) Gulf in Dubai, United Arab Emirates, was organised as a part of the cooperation of the Visegrad Group. The party responsible for this event was the Hungarian National Tourist Organisation. Representatives of the V4 national tourist organisations (Czech Republic, Hungary, Poland and Slovakia) presented the tourist attractions of their countries. Cultural tourism, SPA and medical tourism attracted particular interest. The presentations were followed by workshops of tour operators from V4 countries with local travel agencies. Representatives of around 30 local tourist offices and about 10 local media outlets participated (POT 2014). Then, in February 2015, representatives of the tourist authorities of the Visegrad Group countries signed a Marketing Plan and a protocol regulating the joint promotion of inbound tourism to the countries of the V4 (Gąsior 2015).

In 2017, the Visegrad Group established relations with Israel. On July 192017, the prime ministers of the V4 countries met in Budapest with the Prime Minister of Israel, Benjamin Netanyahu. The summit in Budapest was the first 
meeting of the Visegrad Group with Israel at the level of heads of government. On the occasion of the summit, bilateral meetings of the prime ministers also took place. Netanyahu's visit to Budapest was the first visit by an Israeli prime minister to Hungary since the fall of communism. Hungary, which held the V4 presidency from July 2017-June 2018, actively used the V4+ format for meetings with non-European countries. In early July 2017, V4 prime ministers met with Egyptian president Abdel Fattah al-Sisi. Through meetings with both the Prime Minister of Israel and the President of Egypt, the V4 wanted to strengthen its argumentation in the debate on the migration crisis and the fight against terrorism, which should be accompanied by cooperation with the countries of the region. As part of the Middle East Peace Process, the Visegrad Group advocates a two-state solution, as expressed both in the joint statement of the V4 countries and Egypt on July 4 2017, and in the statement by V4+Israel of July 19. Summit participants stressed the need for cooperation in the field of security and innovation. They announced the creation of working groups for combating terrorism and for supporting technological cooperation, which could be co-financed by the International Visegrad Fund. In the area of security, cooperation will concern, among others, cybersecurity, counter-terrorism and border protection. In terms of innovation, countries have declared their intention to strengthen cooperation in the high-tech sector, including digitisation, start-ups and scientific. The V4 states have also committed themselves to improve EU-Israel relations, in particular, to update the EU-Israel Association Agreement which entered force in 2000. The energy sector offers prospects for cooperation. Israel has started producing natural gas from the Mediterranean Sea. The V4 countries are interested in the diversification of energy sources, and could be natural recipients of Israeli natural gas, also in liquefied form (LNG). The increasing expenditure on the defence of the V4 states is also an attractive market for the Israeli arms industry, as evidenced by, for example, the decision made in 2016 by the Czech government to purchase Israeli radar systems. The experience in cooperation with Israel so far may encourage the V4 to initiate a similar form of dialogue with other Middle Eastern partners or interest in participating in projects also under the Three Seas Initiative, of which V4 countries are a part (Ogrodnik Wojnarowicz 2017). After the V4-Israel meeting in Budapest, two working groups were set up concerning security and combating terrorism, as well as on research, development and innovation. On June 182018, a Memorandum of Understanding was signed on training cooperation in the field of innovation for entrepreneurs from the Visegrad Group countries. Another area of strategic importance is cooperation regarding the arms industry, the purchase of new Israeli technology and weapons, and conducting joint training (Dyduch 2018).

On July 12019, the Czech Republic took over the annual presidency of the V4 emphasising (as had Slovakia before) the dominance of EU issues in Visegrad cooperation. However, their position on European integration was more 
conservative. Babiš's government highlighted more clearly the need for cooperation with the countries of the Western Balkans than with the Eastern Partnership. Meetings in the V4+ format were to serve the better positioning of the Czech Republic and the Visegrad Group in the European Union. Germany was considered as the preferred partner of the Czech Republic in this formula, which Babiš explained with their strong trade relations. The functioning of the Visegrad Battle Group (with the additional participation of Croatia) has been an added V4 contribution to EU security. Its next formation has been announced for the first half of 2023. Regional and European cooperation in the field of migration is of great importance for the ruling party, the Alliance of the New Citizen (ANO), both in domestic and foreign policy. The presidency programme narrowed the sphere of energy cooperation to nuclear power. The focus on it reflects the national assumptions of its development, i.e. the construction of subsequent blocks of the nuclear power plant in Dukovany and government plans to increase nuclear electricity production from $30 \%$ to $58 \%$. The specificity of the $\mathrm{V} 4$ format with the leading role of prime ministers, Babiš's positive attitude towards the group, as well as his cordial contacts with other V4 prime ministers are conducive to efficient coordination of the group's positions in the EU. The postulate of building regional innovation corresponds to the assumptions of the Warsaw Declaration, adopted by Visegrad prime ministers in 2017 during the Polish presidency (Ogrodnik 2019).

\section{Case Studies}

The Visegrad Group countries established diplomatic relations with the United Arab Emirates at the turn of the 1980s and 1990s. This period was exceptional for all V4 countries, Europe and the world, with the visible role of Poland and its Solidarity movement in the fall of communism, including the fall of the Berlin Wall. Consequently, Poland, along with the other countries of the Visegrad Group, contributed to the construction of a new European and world order in the $21^{\text {st }}$ century. In this atmosphere, the V4 countries began to build their new role and international position and to pursue their interests in the world with a new partner, the United Arab Emirates. The current history of relations between the Visegrad Group countries and the UAE is characterised by periods of completely different dynamics and significance. The first period was a time of hard work, signing the first agreements and identifying effective tools to achieve interests. Moreover, at the summit in Slovakia in 2010, the Visegrad Group countries recognised the GCC region, including the United Arab Emirates, as particularly important for the implementation of the V4 vision and strategy in international relations. 


\section{Czech Republic}

In 1988, then Czechoslovakia established diplomatic relations with the United Arab Emirates. In 1993, diplomatic relations were again concluded between the UAE and the newly formed state of the Czech Republic. By 2014, relations were very good in the economic area, including tourism. However, there was a lack of official visits to both countries at the top level. Nevertheless, in March 2014, the UAE Foreign Minister, H.H. Sheikh Abdullah bin Zayed Al Nahyan came to Prague on an official visit during which the UAE Minister emphasised the need for top-level visits between the two countries. During the visit H.H. Sheikh Abdullah bin Zayed Al Nahyan met with President Milos Zeman, Czech Parliament Speaker Jan Hamáček, as well as his counterpart Lubomír Zaorálek. Throughout the visit, the interlocutors emphasised the need to accelerate cooperation, primarily in the field of renewable energy and the peaceful use of nuclear energy and tourism (MOFAIC 2014). Consequently, in February 2015, the President of the Czech Republic, Miloš Zeman, paid an official visit to the United Arab Emirates. It was the first visit of the Czech President to the UAE in history. In addition to official top-level meetings, the president visited the Hedayah, the International Center of Excellence for Countering Violent Extremism and participated in the economic forum of the UAE-Czech Republic, co-organised by the UAE Ministry of Foreign Affairs and the Confederation of Industry of the Czech Republic, and the UAE Federation of the Chambers of Commerce and Industry (Embassy of the Czech Republic in Abu Dhabi 2015a). As a result of the visit of President Miloš Zeman, the UAE government and business delegation came to the Czech Republic in April 2015, headed by the Minister of Economy Sultan Bin Saeed Al Mansouri, as well as representatives of the Dubai Chamber of Commerce and Industry. In addition, heads of seven major Emirati corporations participated in the visit. Members of the delegation showed interest in investing primarily in real estate, tourism, infrastructure and the construction industry. It was the first UAE economic visit to the Czech Republic in bilateral relations. During the Czech-Emirati Business Forum, UAE Minister of Economy Sultan Bin Saeed Al Mansouri presented Pavel Foubík with a certificate of membership for the Czech Business Council to the Dubai Chamber of Commerce and Industry (DCCI). In this way, the Czech business organisation became the first member of Central and Eastern Europe in the DCCI (Embassy of the Czech Republic in Abu Dhabi 2015b). In response to the Emirate delegation's visit to the Czech Republic, in November 2015 the Minister of Industry and Trade of the Czech Republic together with the Czech Chamber of Commerce came to Dubai to continue enhancing and expanding cooperation. For the Dubai Chamber of Commerce and Industry, this mission was another opportunity to implement the strategy of promoting Dubai among partners from Central and Eastern Europe as a place of great opportunities for 
their export and re-export. On September 262018, Speaker of the Chamber of Deputies of the Czech Republic Radek Vondráček came to the United Arab Emirates with an official visit. In addition to the meeting with his counterpart, he had a meeting with H.H. Sheikh Mohammed bin Rashid Al Maktoum - the Vice President, Prime Minister and Ruler of Dubai (MOFAIC 2018). Additionally, in July 2019 another the UAE economic delegation arrived in the Czech Republic. On the basis of the innovation strategy in both countries, partners expressed their interest in dynamising and expanding relations primarily in the areas of smart city solutions, manufacturing, logistics, healthcare, tourism and artificial intelligence (Alghoul - Abubaker 2019).

\section{Hungary}

Diplomatic relations between Hungary and the United Arab Emirates were established in 1990. However, it is worth noting that in 1976, 5 years after the creation of the UAE, the Hungarian Trade Office was opened in Dubai. The historic, first official visit to the United Arab Emirates of Hungarian President Árpád Göncz took place in 1995. However, a Hungarian Embassy wasn't established in Abu Dhabi until 2006. It is also worthy of note that in June 2009 the historic first visit of the Minister for Foreign Affairs of the UAE was undertaken by H.H. Sheikh Abdullah Bin Zayed Al Nahyan. To deepen political relations, in February 2012 Speaker of the National Assembly of Hungary László Kövér visited the United Arab Emirates. From 2015, political and economic relations began to enter a more dynamic stage. The UAE Minister of Economy Sultan Bin Saeed Al Mansouri paid an official visit to Budapest in September the same year. The goal of the minister's mission was to meet the Hungarian economy minister Mihály Varga and to give new dynamics to economic relations (Hanaa 2015). While in the following month of October, the Hungarian Minister of State for Economic Diplomacy Levente Magyar came to the United Arab Emirates to strengthen cooperation and identify new possible areas of mutual interest. During his stay in the UAE, an agreement was signed on political consultations (MOFAIC 2015). The following year, in March 2016, the first UAE-Hungary Joint Economic Committee (JEC) was held in Dubai, chaired by the UAE Minister of Economy Sultan bin Saeed Al Mansouri and the Hungarian Minister of Foreign Affairs and Trade, Péter Szijjártó. The talks focused on looking for ways to deepen relations in areas such as investment, trade, energy, small and medium-sized enterprises (SMEs), agriculture and environment, water management, health, tourism, ICT, transport and intellectual property. After only a few months, in July 2016, the Minister of Foreign Affairs and International Cooperation H.H. Sheikh Abdullah bin Zayed Al Nahyan visited the Hungarian capital Budapest. The UAE Minister had a meeting with his counterpart Péter Szijjártó, Hungarian Minister of National Economy Mihály Varga and others. During the meetings, 
topics were discussed, first of all concerning political and economic cooperation and involvement in investment partnership. In the course of his stay in Hungary, the Minister of Foreign Affairs of the United Arab Emirates H.H. Sheikh Abdullah bin Zayed Al Nahyan expressed interest in deepening and expanding relations with Central and Eastern Europe, primarily in areas such as economy, trade, investment and cooperation in the field of security (MOFAIC 2016). Due to the new dynamics of relations between the two countries, the Embassy of the United Arab Emirates in Budapest was established in 2018. In November of the same year, the Hungarian Minister of Foreign Affairs and Trade, Péter Szijjártó, visited the UAE, during which two agreements were signed. One of them is MoU on security and counter-terrorism cooperation, which was signed between the interior ministries of the two countries, and the other, MoU on cooperation in academic research, was signed between the Emirates Diplomatic Academy and the Hungarian Institute for Foreign Affairs and Trade (MOFAIC 2018). Maintaining the dynamics of the visits, a few months later, in March 2019, the $2^{\text {nd }}$ Joint Economic Committee was held in Budapest, chaired by the Minister of Foreign Affairs and Trade of Hungary Péter Szijjártó and the UAE Minister of Economy Sultan bin Saeed Al Mansouri. During the visit, the agreement was signed between the UAE Ministry of Economy and the Ministry of Innovation and Technology of Hungary MoU on cooperation in science, technology and innovation. Besides, it was agreed to strengthen relations in areas such as investment, trade, industry, innovation, renewable energy, science, technology, telecommunications, aviation, tourism, education, culture, insurance and Halal accreditation (MOFAIC 2019).

\section{Poland}

At an exceptional time, in the year of the fall of communism in Poland, which contributed to changes in Europe, including the fall of the Berlin Wall, on September 41989 Poland established diplomatic relations with the United Arab Emirates. In the years 1989-2010, Poland's relations with the Middle East underwent very variable dynamics. This time should be divided into two periods: 1989-2003 and 2004-2010. Initially, the first period was characterised by a new opening to cooperation with new partners, signing first agreements and creating a cooperation framework. However, since 1995 there has been a drastic reduction in the dynamics of relations. Although after the start of the Iraq war in 2003, there was a renewed interest in the Middle East. Therefore, in 2004 the strategy of the Polish government was adopted, which initiated a new approach to this region. The Council of Ministers has identified the UAE as one of five of the most important countries of the Middle East for Polish foreign and security policy. During his second term of office, President Aleksander Kwaśniewski paid official and working visits to 10 Middle East countries, including the United Arab 
Emirates. In addition, President Lech Kaczyński also identified the Middle East as a key region for Poland's foreign and security policy (Bieleń 2011: 392-394).

Until 2011, relations between Poland and the United Arab Emirates were positive, but they were not characterised by greater dynamics. However, their relations have changed significantly since 2011, giving them a strategic dimension. At the turn of February and March 2011, the Minister of Agriculture and Rural Development paid a visit to the UAE. As a result, a few months later Poland was one of the first EU countries to lift the ban on Polish beef imports. In May 2011, the first visit of the UAE Minister of Foreign Affairs to Poland H.H. Sheikh Abdullah bin Zayed Al Nahyan took place. At the invitation of Crown Prince of Abu Dhabi, in January 2012 a visit to the United Arab Emirates was made by the Deputy Prime Minister and the Minister of Economy. In April the same year, Prime Minister Donald Tusk arrived in the United Arab Emirates on an official visit both in Abu Dhabi and Dubai. It was the first visit of the Polish government's prime minister since 1994. In June 2012, the UAE Minister of Economy Sultan Bin Saeed Al Mansouri visited Poland, where he met with Prime Minister Donald Tusk, as well as the Deputy Prime Minister and the Minister of Economy. This year the decision was made by Emirates Airline to launch a connection between Dubai and Warsaw. In February 2013, the first meeting of the Joint Commission for Economic Cooperation took place in Poland at the level of economy ministers. The President of the Republic of Poland Bronisław Komorowski paid an official visit to the United Arab Emirates in December 2013. It is also worth underlining that just a few months later on March 22, 2014, the obligation to apply for an entry visa to the UAE was lifted for Polish citizens. Moreover, in June of the same year H.H. Sheikh Abdullah bin Zayed Al Nahyan, UAE Minister of Foreign Affairs paid an official visit to Poland again. Continuing the dynamics of relations between the partners, in April 2015 the Deputy Prime Minister and Minister of Economy Janusz Piechociński came to the UAE, where he met with the UAE leaders, and participated in two economic forums, both in Abu Dhabi and Dubai. Additionally, the second meeting of the Joint Commission for Economic Cooperation took place (Krzymowski 2017: 54-55).

Particularly noteworthy is the official visit to Poland by His Highness Sheikh Mohammed Bin Rashid Al Maktoum - Vice President, Prime Minister of the United Arab Emirates, and Ruler of Dubai - on 7-9 June 2015. It was the first historic visit to Poland at such a high level. The UAE side announced that Poland had reached the level of strategic partner for the United Arab Emirates. In addition to official meetings, the following agreements were signed during the visit: Agreement on cooperation in the field of innovation and small and medium-sized enterprises; Memorandum of Understanding in the fields of agriculture, food safety, research cooperation and marketing in agriculture and food; Memorandum of Understanding between Governments on Cooperation in Higher Education and Research; Agreement on cooperation in the field of 
tourism. In addition, there was a meeting of His Highness Sheikh Mohammed Bin Rashid Al Maktoum with the President-Elect Andrzej Duda, for whom the Ruler of Dubai was the first foreign guest. His Highness emphasised that the fifth year of dynamic development of very close relations had begun and he expressed hope for the further development of these relations (Krzymowski 2017: 141-144).

However, when analysing the successive years of relations between Poland and the UAE, it should be noted that between 2016-2017 no official bilateral visit at the ministerial level or above took place. Moreover, trade began to decline drastically. After 2015, there was no meeting of the Joint Commission for Economic Cooperation. As a consequence of the decision of the UAE authorities in 2015 to grant Poland the status of the Guest of Honour at the International Book Fair in Abu Dhabi, which took place on April 24-27 2018, the official opening of this event was attended by Deputy Prime Minister and Minister of Culture and National Heritage Piotr Gliński. In February 2019, the Minister of Agriculture and Rural Development Jan Ardanowski took part in the GulfFood fair in Dubai. In November 2019, the Minister of Infrastructure and Development Abdullah Belhaif Al Nuaimi came to Poland, where a maritime transport agreement was signed, the negotiations of which were completed in April 2015. On October 152019, the Ruler of Sharjah H.H. Sheikh Sultan Bin Muhammad Al Qasimi came to Krakow on a private visit at the invitation of the Jagiellonian University. This visit was the result of direct cooperation between the Jagiellonian University and the University of Sharjah, whose president is the Ruler of Dubai.

\section{Slovakia}

Diplomatic relations between Slovakia and the United Arab Emirates were established in 1993. They recorded different periods until the end of 2013 when the embassy was reopened after nearly ten years. Since then, and above all since 2015, there has been a dynamic development of cooperation between the two countries. In June 2014, Deputy Prime Minister and Minister of Foreign and European Affairs of Slovakia Miroslav Lajčák came to the UAE, where during a conversation with the UAE Minister of Foreign Affairs and International Cooperation, H.H. Sheikh Abdullah bin Zayed Al Nahyan, partners expressed their readiness to increase relations to the highest level of cooperation, both political and economic (MOFAIC 2014). In April 2015, in the capital of Slovakia, Bratislava, Minister Miroslav Lajčák together with the UAE Minister of Economy Sultan Bin Saeed Al Mansouri signed MoU on establishing a Joint Economic Committee to further deepen economic, trade and investment cooperation (MOFEA 2015). Besides that, also the MoU on security cooperation and counter-terrorism and the MoU on mutual recognition of driving licenses issued by the two countries 
was signed. Following the dynamics of cooperation, in December 2015 Prime Minister of the Slovak Republic, Robert Fico came to the United Arab Emirates on an official visit, where he opened the Embassy in Abu Dhabi and the Agreement on avoiding double taxation was signed. Talks during meetings with UAE leaders focused on deepening economic and investment cooperation, promoting common interests in the international environment, as well as regional and global challenges, including those related to EU security policy (MOFAIC 2015). While on the occasion of the UN General Assembly in New York in September 2016, the UAE Minister for Foreign Affairs and International Cooperation H.H. Sheikh Abdullah Bin Zayed Al Nahyan and Minister of Foreign and European Affairs of the Slovak Republic Miroslav Lajčák signed a bilateral agreement on mutual protection and promotion of investment (MOFEA 2016). However, in July 2017, the UAE Minister for Foreign Affairs, H.H. Sheikh Abdullah bin Zayed $\mathrm{Al}$ Nahyan paid the first ever official visit of that office to Slovakia in history. During the meeting with his counterpart, both sides emphasised that apart from the development of economic relations, there is a need to dynamise relations in the area of security. Moreover, the position was expressed that it would be in the interest of both parties to sign a free trade agreement between the European Union and the GCC. During the meeting, the MoU on the mechanism of political consultations was signed (MOFEA 2017). It is also worth mentioning that the UAE Minister for Foreign Affairs and International Cooperation also met with Slovakia's Deputy Prime Minister and Minister of Interior Robert Kaliňák and Prime Minister Robert Fico to discuss the international situation, including in the Middle East, and strategic elements of bilateral cooperation (MOFAIC 2017). In response to the deepened cooperation of both partners, in April 2018 the UAE Deputy Prime Minister and Minister of the Interior, H.H. Lt. General Sheikh Saif bin Zayed Al Nahyan paid an official visit to Bratislava. During the meeting with Speaker of the Parliament of Slovakia Andrej Danko, both parties emphasised their readiness to deepen the relationship and raise it to the level of strategic partnership. During the meeting with the Prime Minister Peter Pellegrini, MoUs on offering medical treatment in hospitals in Slovakia to UAE soldiers who were injured in Yemen as well as rehabilitation programs and aftercare services in specialist health institutions was signed. The UAE Deputy Prime Minister and Minister of the Interior were also accompanied by representatives of the Mubadala Group, Fly Dubai and Etihad Airways (Hazem Hassan 2018) during the official visit to Slovakia. It is also worth noting that in July 2019, Slovakia, as one of the nine countries and the only country from the V4, participated in the first common security exercise of the International Security Alliance (ISALEX19). This initiative started in 2017 in Abu Dhabi as an international working group to combat organised, transnational and extremist crime. In the framework of this initiative, countries should combine security efforts in joint practices as well as expertise (Alfaham - Hassan 2019). 


\section{Empirical Findings}

When carrying out a detailed analysis of official visits of the highest level of the Visegrad Group countries in bilateral relations with the United Arab Emirates from the last ten years, it should be noted that in the period 2011-2015 Poland was the clear leader. The Czech Republic and Slovakia show the same dynamics, which are much smaller than Poland. During this period, Hungary made only one visit at this level. However, in the period from July 2015 to June 2020 the situation completely reversed. During this period, Poland had/paid/register no visits, and the Czech Republic didn't carry out an official top-level visit. However, frequent economic missions took place at that time. Hungary, on the other hand, became the leader, and Slovakia tried to maintain the dynamics of visits.

The chart below presents the dynamics of the most important official bilateral visits, including visits at the level of heads of state and government, as well as Ministers of Foreign Affairs, the Economy and members of royal families in high state positions.

Analysing the trade exchange of the last 10 years, especially the exports of the Visegrad Group countries to the United Arab Emirates, it should be underlined that until 2014 Poland was the leader of growth dynamics and Hungary recorded the largest decrease at that time. The Czech Republic and Slovakia recorded a stable increase in exports. However, after 2015, Poland shows the largest decrease in exports. Hungary, on the other hand, began to contain negative trends and Slovakia had started a stable increase in exports. While the Czech Republic after 2018 shows a high dynamics of export growth to the United Arab Emirates.

\section{Figure 1: The most important official bilateral visits of V4 countries with the UAE}

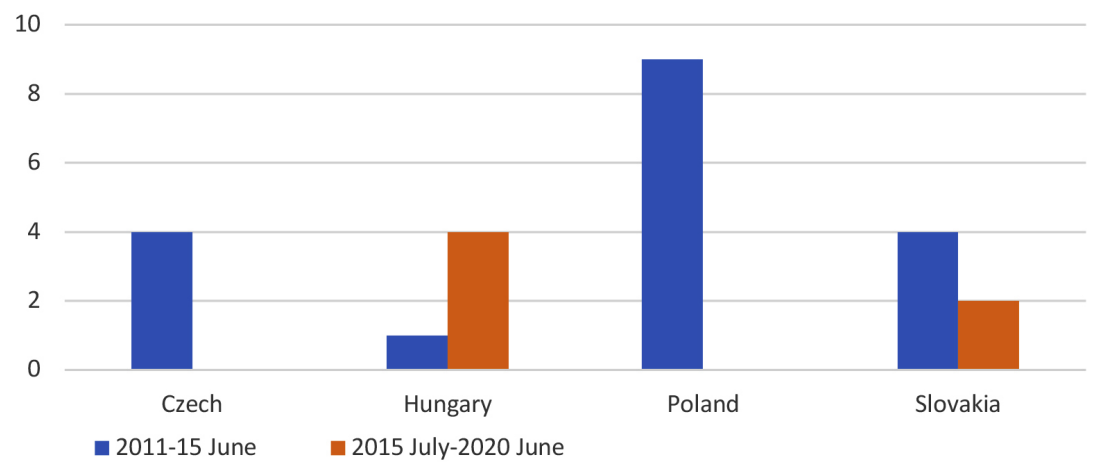

Source: elaboration of the author - based on data from government institutions 


\section{Figure 2: Export of V4 countries to the United Arab Emirates in US \$}

(in thousand)

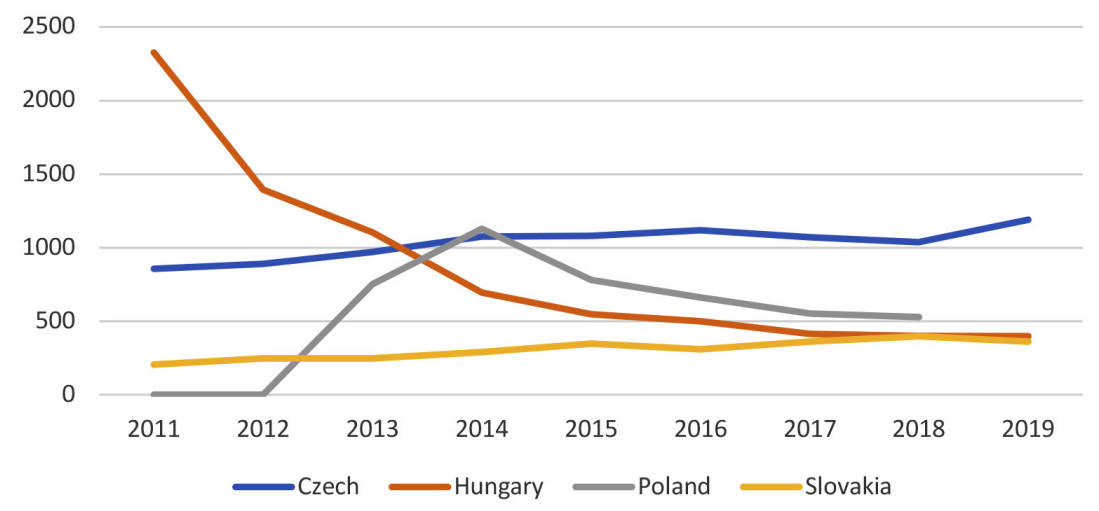

Source: elaboration of the author - based on data from government institutions

Comparing the findings of research on both the dynamics of the most important official bilateral visits, as well as the exports of the Visegrad Group countries to the United Arab Emirates, it should be stated that in the period 2011-2015 Poland was the clear leader. However, after 2015 the country fell to the last place. In the case of the Czech Republic, it should be emphasised that although no official top-level visit has taken place since 2016, the results show that the country is the export leader to the UAE, with the support of government economic missions. Moreover, since 2018 the Czech Republic has had great dynamic growth of trade exchange. Hungary, despite a large drop in exports, has slowed down since 2015. In addition, since then the country has been showing high dynamics of economic visits at ministerial level, including meetings of the Joint Economic Commission, becoming a V4 leader regarding visits. Due to the specifics of the United Arab Emirates, these official economic visits should also soon affect the re-growth of trade.

The research shows that the V4 countries and the United Arab Emirates, which emphasise the huge interest in strategic cooperation with Central and Eastern Europe, have great opportunities to establish and deepen relations in many areas. The United Arab Emirates is a country with a geostrategic orientation related to the transatlantic area. The UAE is an important member of NATO's Istanbul Cooperation Initiative, as the first country in the Arab world to have its ambassador at NATO headquarters. In addition, the United Arab Emirates is involved in deepening relations with the European Union by undertaking joint initiatives. In 2015, this small country became the seventh biggest recipient of goods from the EU in the world. And, for the United Arab 
Emirates, the European Union has become the largest trading partner. Sustainable Development Goals have been an important element of cooperation since 2015 (Krzymowski 2020: 216). However, in order to deepen political dialogue, a cooperation agreement was signed in January 2018 between the European External Action Service and the UAE Ministry of Foreign Affairs and International Cooperation (EEAS 2018). Exactly a year later, High Representative of the European Union for Foreign Affairs and Security Policy and Vice President of the European Commission, Federica Mogherini, stated that the United Arab Emirates is a strategic ally of the European Union. Moreover, in February 2020 the European Maritime Awareness mission in the Strait of Hormuz (EMASOH), with headquarters in Abu Dhabi, the capital of the United Arab Emirates (Embassy of France in Abu Dhabi 2020), achieved full operation. It should also be remembered that since 2009 there is a permanent French military base in Abu Dhabi. The European Union and the United Arab Emirates have in the Middle East and North Africa a common interest in countering terrorism and ensuring stability. That is why the European Union got involved in establishing in September 2011 the Hedayah, the International Center of Excellence for Countering Violent Extremism, in which the EU is one of the board members. It is worth mentioning that in 2015 the President of the Czech Republic also visited this organisation during an official visit. Additionally, since June 2014 Abu Dhabi has been the regional headquarters of the European Union Chemical, Biological, Radiological, and Nuclear Center of Excellence.

The strategic goal of the Visegrad Group is the European Union, which can be an effective tool for pursuing V4 interests also outside its area (Krzymowski 2011: 46). It should be noted that the summit of the Visegrad Group with the participation of the President of Egypt, Abdel Fattah al-Sisi, took place in Budapest on July 42017 , so only two days before the 3SI summit, in which President of the United States Donald Trump participated. For Russia, Egypt is a key country with which it can become one of the main players in the MENA region. Thus, the V4 is an important part of a broader strategic plan, including shaping power in the Middle East and North Africa region. One should agree with Repetowicz (2017) that the Visegrad Group's cooperation with Egypt in this regard is the assumption by the countries of Central and Eastern Europe of responsibility for the Mediterranean. After the meeting in Budapest, the joint press conference focused on Egypt's role in stabilising the Middle East and North Africa, in particular in controlling and combating illegal migration. The talks also concerned Libya, in which the stabilisation efforts of General Haftar are supported by Egypt and the United Arab Emirates (Repetowicz 2017).

The arms industry is one of the potential areas for strengthening relations between the United Arab Emirates and the Visegrad Group countries. It is worth mentioning that in February 2017 in Abu Dhabi, during the largest defence trade fair (the International Defence Exhibition \& Conference, IDEX), the Czech 
state company VOP CZ signed an agreement with NIMR Automotive, which is part of the state-owned Emirates Defence Industries Company. The contract provides for the installation of the assembly line at the VOP CZ plant in Šenov near Nový Jičín and the installation of the Ajban 440A / N car service centre as well as other NIMR Automotive vehicles in the Czech Republic. Besides, the contract also offers armoured vehicles in the countries of the Visegrad Group (Multarzyński 2017). As a result of talks initiated in 2014, a decision was made after a year to sell to the United Arab Emirates 40 base chassis of Rosomak wheeled armoured personnel carriers, implemented by the Polish company Rosomak S.A. It is worth recalling that in July 2015 the prime ministers of Poland, Ewa Kopacz, and of Slovakia, Robert Fico, announced the selection of the Rosomak turret Scipio for the Slovak army. However, an agreement has not been finalised. In November 2019, the Polish company Rosomak from Siemianowice Śląskie obtained a license that allows cooperation on foreign markets, including offering a new platform to foreign markets. This in turn creates new opportunities for cooperation within the armaments industry of the Visegrad Group countries, including the United Arab Emirates (Muczyński 2020). Currently, the centre-right government of Slovakia led by Igor Matovič, sworn in on March 212020, is sending signals about new opportunities for Polish-Slovak cooperation and a return to the KTO Scipio project based on the Rosomak and the Slovak Turra 30 tower. Additionally, in foreign and security policy the new government strongly emphasises the Euro-Atlantic orientation and active participation in the Visegrad Group, including increasing its role. Prime Minister Matovič emphasises the need to deepen 'above-standard' relations with the Czech Republic and 'proven cooperation with Poland' (Dębiec 2020). Thus, there are favourable conditions for the Visegrad Group to achieve greater dynamics of cooperation after 30 years of operation, including the shaping of the international environment in the Middle East.

\section{Conclusion}

From 2010, relations between the United Arab Emirates and European Union countries began to gain greater momentum. This is primarily the result of a change in the geopolitical priorities of the US foreign and security policy, redirecting their strategic interests from Europe, as well as the Middle East, to East Asia. At that time, the Lisbon Treaty came into force, which further continued the creation of new instruments for the Common Foreign and Security Policy (Krzymowski - Krzymowska 2019: 25). Moreover, after a year of its operation, the so-called Arab Spring forced the EU to become more involved in the Middle East. In addition, it should be remembered that the world has just started to recover from the global economic crisis that originated in the United States. In such a situation, the European Union and the United Arab Emirates, the most 
stable country in the Middle East, became a natural partner for enhance cooperation. It is also worth noting that a year after the war in Iraq started in 2003 by the US and its coalition partners, the UAE and Germany started a strategic partnership. And in 2009 a French permanent military base was opened in the capital of the United Arab Emirates, the first in an area that was not its colony. These new impulses convinced both the European Union and the UAE to the need to deepen and broaden their relations. Additionally, within the United Arab Emirates' strategy to transition to a green economy, abandon oil as one of the main sources of income and invest in renewable energy, the European Union has gained additional attractiveness as a partner and leader. Taking into account the concepts of the UAE's foreign and security policy consisting of the diversification of the alliance, the country has taken steps to establish and strengthen relations with the countries of Central and Eastern Europe, including the Visegrad Group. From October 2021 to March 2022, the World Expo 2020 will be held in Dubai, the first in the region of Southwest Asia, the Middle East and North Africa. It will be a great opportunity to present joint projects of the Visegrad Group, as well as a unique opportunity to develop partnerships under the V4+ formula. However, it should be emphasised that despite the fact that the GCC has been recognised as an important partner for the Visegrad Group in 2010, no official meeting between the V4 and the Gulf Cooperation Council has taken place so far. Undoubtedly, closer cooperation between the two regions will bring tangible benefits, political, economic, cultural and in the area of security. Moreover, this cooperation could be an effective platform for solving common global challenges, including those related to climate change. The cooperation between the Visegrad Group and the United Arab Emirates should be an example and a model that will also be used by other GCC members. Active in the European Union, the Visegrad Group, setting the directions for the development of 3SI and being in a strategic partnership with the USA, may become an effective element of a broader strategy, of global importance, of economic, foreign and security policy, covering Europe, North Africa and the Middle East.

\section{References}

Alfaham, Tariq - Hassan, Bashir (2019): Abu Dhabi to host first ISA's joint security exercise ISALEX19, WAM: available at http://wam.ae/en/details/1395302771014 (11 March 2020).

Alghoul, Rola - Abubaker, Rasha (2019): Dubai, Prague build new bridges of economic cooperation, WAM: available at http://wam.ae/en/details/1395302772811 (15 May 2020).

Bieleń, Stanislaw (ed): Poland's foreign policy in the 2115t century, Warsaw 2011, 392-394. 
Cabada, Ladislav - Waisová, Šárka (2018): The Visegrad Group as an Ambitious Actor of (Central-) European Foreign and Security Policy, Politics in Central Europe, 14 (2). 9-20.

Czech Presidency (2011): Innovative Visegrad: Programme of the Czech Presidency of the Visegrad Group 2011-2012: available at http://www.visegradgroup.eu/documents/presidency-programs/innovative-visegrad (17 March 2020).

Dębiec, Krzysztof (2020): Słowacja: rząd Matoviča z programem na trudne czasy, OSW Analizy: available at https://www.osw.waw.pl/pl/publikacje/analizy/2020-04-22/slowacjarzad-matovica-z-programem-na-trudne-czasy (17 June 2020).

Dyduch, Joanna (2018): The Visegrad Group's Policy towards Israel. Common Values and Interests as a Catalyst for Cooperation. SWP Comment 2018/C 54, December 2018: available at https://www.swp-berlin.org/fileadmin/contents/products/comments/2018C54_Dyduch.pdf (15 May 2020).

EEAS (2018): EU and UAE sign a Cooperation Arrangement. Press releases: 180131_15. Bruxelles: available at https://eeas.europa.eu/headquarters/headQuarters-homepage_it/39170/EU\%20 and\%20UAE\%20sign\%20a\%20Cooperation\%20Arrangement (14 June 2020).

Embassy of the Czech Republic in Abu Dhabi (2015a): Official visit of the Czech President in the United Arab Emirates: available at https://www.mzv.cz/abudhabi/en/culture_and_events/ official_visit_of_the_czech_president_in.html (4 May 2020).

Embassy of the Czech Republic in Abu Dhabi (2015b): Historically $1^{\text {st }}$ mission of Emirati investors visits the Czech Republic: available at https://www.mzv.cz/abudhabi/en/economy_trade/ historically_1st_mission_of_emirati.html (14 May 2020).

Embassy of France in Abu Dhabi (2020): Visit of Laurent Fabius to the United Arab Emirates: available at https://ae.ambafrance.org/Visit-of-Laurent-Fabius-to-the-United-Arab-Emirates (15 June 2020).

Gąsior, Adam (2015): Czechy, Polska, Stowacja i Węgry będą się wspólnie promować: available at https://www.waszaturystyka.pl/czechy-polska-slowacja-i-wegry-beda-sie-wspolnie-promowac/ (30 June 2020).

Grabiński, Tomasz (2020): The Summit in the Frosty Ruins: The Background of the 1991 Visegrad Meeting: available at http://www.visegradgroup.eu/the-visegrad-book/grabinski-tomasz-the (17 April 2020).

Hanaa, Moran (2015): Al Mansouri and his Hungarian counterpart discuss cooperation, WAM: available at http://wam.ae/en/details/1395285584320 (11 May 2020).

Hazem, Hussein - Hassan, Bashir (2019): Saif bin Zayed meets with Speaker of Slovakian Parliament, WAM: available at http://wam.ae/en/details/1395302684759 (1 May, 2020).

Hungarian Presidency (2013): Hungarian Presidency in the Visegrad Group (2013-2014): available at http://www.visegradgroup.eu/documents/presidency-programs/20132014-hungarian (17 March 2020).

Krzymowski, Adam (2011): Francja i RFN na Bliskim Wschodzie i w Afryce Północnej - Współpraca Czy Rywalizacja, Zeszyty Naukowe AON nr 4(85).Krzymowski, Adam (2017): Republic of Poland \& United Arab Emirates. 25 Years of Diplomatic Relations, Mohammed bin Rashid Al Maktoum Knowledge Foundation. 
Krzymowski, Adam (2020): Sustainable Development Goals in Arab Region - UAE' Case Study, Problems of Sustainable Development,15(1), 2020, European Academy of Science and Arts, Salzburg.

Krzymowski, Adam - Krzymowska, Kinga (2019): Lisbon Treaty (2009-2019) on the Journey to Achieve the European Union as an Effective Global Actor, Journal of Central and Eastern Europe, No 11/2019.

MOFAIC (2015): Abu Dhabi Crown Prince receives Slovak Prime Minister: available at https:// www.mofaic.gov.ae/en/MediaHub/News/2015/12/22/221215-slovakia (14 May, 2020).

MOFAIC (2016): Al Mansouri and his Hungarian counterpart discuss cooperation: available at https://www.mofaic.gov.ae/en/MediaHub/News/2016/7/14/1472016-Hungary (18 May 2020).

MOFAIC (2014): H.H. Sheikh Abdullah bin Zayed, Czech counterpart discuss cooperation: available at https://www.mofaic.gov.ae/en/MediaHub/News/2014/3/20/200314-czech2 (4 May 2020).

MOFAIC (2016): H.H. Sheikh Abdullah bin Zayed meets Hungarian Defence Minister: available at https://www.mofaic.gov.ae/en/MediaHub/News/2016/7/14/1472016-Hungary (7 June 2020).

MOFAIC (2017): H.H. Sheikh Abdullah bin Zayed meets with Slovakian foreign Minister: available at https://www.mofaic.gov.ae/en/MediaHub/News/2017/7/13/13-07-2017-UAE-Slovakia (11 March 2020).

MOFAIC (2017b): H.H. Sheikh Abdullah bin Zayed meets with Slovakian Prime Minister: available at https://www.mofaic.gov.ae/en/MediaHub/News/2017/7/13/13-07-2017-UAE-Slovakia (14 May 2020).

MOFAIC (2018): H.H. Sheikh Abdullah bin Zayed receives Hungarian FM: available at https://www. mofaic.gov.ae/en/MediaHub/News/2018/11/12/12-11-2018-UAE-Foreign-Minister-of-Hungary (14 May 2020).

MOFAIC (2014): H.H. Sheikh Abdullah bin Zayed receives Slovak Deputy Prime Minister and Foreign Minister: available at https:/www.mofaic.gov.ae/en/MediaHub/News/2014/6/9/090614slovak (11 May 2020).

MOFAIC (2018): His Highness Sheikh Mohammed bin Rashid receives Chairman of Czech Lower House of Parliament: available at https://www.mofaic.gov.ae/en/MediaHub/ News/2018/9/26/26-09-2018-UAE-Czech-Republic (15 May 2020).

MOFAIC (2020): Official visit of the Czech President in the United Arab Emirates: available at https://www.mzv.cz/abudhabi/en/culture_and_events/official_visit_of_the_czech_president_in.html (4 May 2020).

MOFAIC (2015): UAE-Hungary cooperation discussed: available at https://www.mofaic.gov.ae/ en/MediaHub/News/2015/10/26/261015-Hungary (15 May 2020).

MOFAIC (2015): UAE-Hungary cooperation discussed: available at https://www.mofaic.gov.ae/ en/MediaHub/News/2015/10/26/261015-Hungary (15 May 2020).

MOFAIC (2019): UAE, Hungary strengthening economic cooperation: available at https://www. mofaic.gov.ae/en/MediaHub/News/2019/3/25/25-03-2019-UAE-Hungary (15 May 2020).

MOFAT (2017): 2017-2018 Hungarian Presidency: available at http://www.visegradgroup.eu/ documents/2017-2018-hungarian/20172018-hungarian (15 March 2020). 
MOFEA (2017): Lajčák: Our relations with the United Arab Emirates experience a renaissance: available at https://www.mzv.sk/web/en/ministry/minister/activities/-/asset_publisher/ nNnVuDsSsgB1/content/m-lajcak-nase-vztahy-so-spojenymi-arabskymi-emiratmi-zazivaju-renesanciu/10182 (11 March 2020).

MOFEA (2016): Minister Lajčák in New York: Preventive diplomacy and mediation are the most effective instruments for conflict prevention: available at https://www.mzv.sk/web/en/ news/detail/-/asset_publisher/oLViwP07vPxv/content/m-lajcak-v-new-yorku-preventivna-diplomacia-a-mediacia-su-najefektivnejsie-nastroje-na-predchadzanie-konfliktov/10182 (11 April 2020).

MOFEA (2015): SR and the United Arab Emirates deepen their economic cooperation: available at https://www.mzv.sk/web/en/news/detail/-/asset_publisher/oLViwP07vPxv/content/sr-and-the-united-arab-emirates-deepen-their-economic-cooperation/10182 (11 March 2020).

Muczyński, Rafał (2020): Przyszłość Rosomaka XP w Polsce. MILMAG: available at https://www. milmag.pl/news/view?news_id=3872 (7 July 2020).

Multarzyński, Mateusz (2017): Czeski NIMR, Wojsko i Technika 10/2017: available at http://zbiam. pl/artykuty/czeski-nimr/ (5 July 2020).

Ogrodnik, Łukasz (2019): 'Rozsądna Europa' - przewodnictwo Czech w Grupie Wyszehradzkiej, Biuletyn 99 (1847): available at https://www.pism.pl/publikacje/Rozsadna_Europa_przewodnictwo_Czech_w_Grupie_Wyszehradzkiej (14 April 2020).

Ogrodnik, Łukasz - Wojnarowicz, Michat (2017): Szczyt V4 + Izrael w Budapeszcie, Komentarz 42/2017: available at https://www.pism.pl/publikacje/Szczyt_V4_Izrael_w_Budapeszcie (14 April 2020).

POT (2014): Promocja Grupy Wyszehradzkiej w Dubaju: available at https://www.pot.gov.pl/pl/ archiwum/promocja-grupy-wyszehradzkiej-w-dubaju\#t (15 March 2020).

Repetowicz, Witold (2017): Trump w Polsce: Trójmorze a Bliski Wschód: available at https://www. defence24.pl/trump-w-polsce-trojmorze-a-bliski-wschod-analiza (17 June 2020).

Slovak Presidency (2010): Program of the Slovak Presidency of the Visegrad Group (July 2010June 2011): Efficient Visegrad-Continuity, Cohesion, Solidarity, Awareness: available at http:// www.visegradgroup.eu/documents/presidency-programs/2010-2011-slovak-110412 (17 March 2020).

Adam Krzymowski is a former Ambassador of Poland to the United Arab Emirates, Representative to the International Renewable Energy Agency, Prime Minister's counsellor, Chief Specialist at the Office of the Committee for European Integration, Senior Advisor to Expo2020 Dubai and Professor (part time) at Sorbonne University, New York University (Abu Dhabi), and University of Sharjah. Currently at Zayed University. ORCID: 0000-0001-9296-6387.E-mail:ak7@vp.pl. 